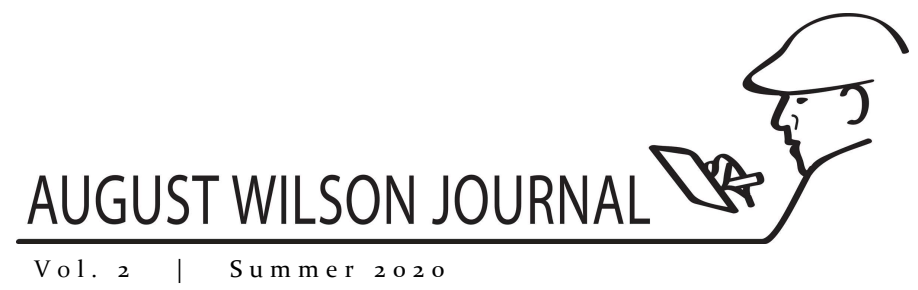

\title{
Subverting the Role of Les Lieux de Memoire: Alaga Syrup as a Symbol in King Hedley II
}

\author{
By Christopher Bell \\ Associate Professor of English, University of North Georgia
}

\begin{abstract}
While the Alaga Billboard may evoke fond memories for those who recognize it, by the 1980s the Hill District, the setting of the play, was a food desert, a community wherein no healthy food options exist, and the product was no longer available in the neighborhood, rendering the presence of the Alaga billboard a negative symbol which complements Wilson's depiction of the neighborhood as one that steadily declines during the second half of the Twentieth Century.
\end{abstract}

- Christopher Bell

\begin{abstract}
An analysis of the impact Alaga Syrup has had on Black communities and its relevance within August Wilson's play, King Hedley II.

Keywords

August Wilson, Alaga Syrup, King Hedley II, Hill District, lieu de mémoire
\end{abstract}

\section{Introduction}

King Hedley II, the ninth play chronologically in August Wilson's much lauded American Century Cycle, is the playwright's darkest play. Set in 1985, approximately thirty years after the City of Pittsburgh began its so-called urban renewal project meant to revitalize the run-down Hill District neighborhood. The play focuses on the nadir of this plan. Beginning in the early 1950s, the city began demolishing the Lower Hill, displacing thousands of residents and shuttering hundreds of businesses. The Civic Arena was erected, establishing a tremendous source of income for both the white power structure and white owned businesses such as the Pittsburgh Penguins, while the Hill District benefitted little. The city reneged on its promise to build affordable, comfortable, modern housing. Wilson scholar Sandra Shannon notes that the Hill District in 1985 is an area besieged by "guns, crime, family dysfunction, and neglect[,]" while the policies of the Reagan administration "brought an attempt to cripple the New Deal and the Great Society by cutting federal support for virtually every program important to African Americans . . . By 1985, many neighborhoods [within the Hill District] that had once been run-down but still thriving and vital became virtual ghost towns - or, worse, savage war zones" (126 - 127). Wilson reflects this veritable wasteland in his 
stark set description: "The setting is the backyards of three houses. One of the houses is missing" (5). In an interview, the playwright elaborated on the play's background: "Look at the sets ... . we've got a torn-down building where the guy plants some seeds and then puts barbed wire around the seeds, and everyone's walking around with $9 \mathrm{mms}$ under their belts. It looks like a war zone - like someone dropped a bomb there" (qtd. in Herrington 169). In closing the set description, however, Wilson adds something curious. He writes that "Buildings across the street in the front of the house are visible through the vacant lot and an old advertisement for Alaga Syrup featuring a faded portrait of Willie Mays is painted on one of the buildings" (King Hedley II 5-6). Interestingly, Mays did in fact endorse this syrup in a series of campaigns for about ten years, beginning in the mid-1950s. Wilson provokes the audience to ponder the inclusion of a billboard in the set description that would have been between twenty and thirty years old, peddling a product no longer available for purchase in the Hill by 1985 , as will be shown later in this essay. Curiously, no scholarly commentary exists that addresses the billboard.

One can build a foundational understanding of the Alaga Syrup billboard by examining it as a lieu de mémoire. The French historian Pierre Nora writes that a site of memory is "where memory crystallizes and secretes itself . . . where consciousness of a break with the past is bound up with the sense that memory has been torn ... There are ... [only] sites of memory . . . because there are no longer . . . real environments of memory" (7). The Alaga billboard fits Nora's definition. By 1985, the Hill District that existed in the 1950s or 1960s when the billboard was erected was unrecognizable. The billboard evokes a sense of past time that is unrecognizable in the present, save the billboard itself.

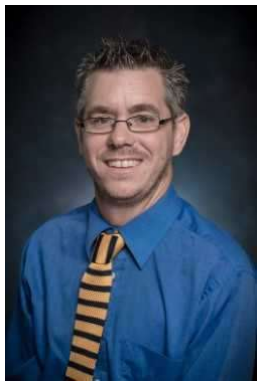

Christopher Bell

Nora also notes that history is fractured, particularly for communities like the marginalized African Americans Wilson writes about. Nora writes, "[A] process of interior decolonization has affected ethnic minorities, families, and groups that until now have possessed reserves of memory but little or no historical capital" (7). For Black Americans, particularly the impoverished ones cut off from mainstream society, this is particularly true. As Wilson himself told Christopher Bigsby, “These kids today ... don't even know about [their ancestors]. They know nothing about that part of their lives and their connection to it ... The connection is broken" (212). The playwright, however, does not blame the younger generation, but asserts they (and all Blacks) are victims of history. To remedy this, he seeks to rewrite history, telling David Savran in an interview that "the history of Blacks in America has not been written by Blacks . . . [and] if we're [African Americans] going to be pointed toward a future, we must know our past" (27). Wilson seeks to provide the "historical capital" missing from the Black community in his drama in order to compel the "reaction, progress, or . . revolution" Nora mentions (7). On the surface, the Alaga billboard, with its evocation of the past, fits this mission.

Furthermore, preserving history, offering an understanding of how institutional racism crippled the Hill District in particular, lies at the heart of King Hedley II, although it should be noted that Wilson does not completely exonerate African Americans from the dissolution of the Black community in this play. Indeed, Harry Elam notes that the Hill District in 1985 is devastated by "systematic abandonment, internalized oppression, and self-destructive violence" (69). The Hill District of his youth that Wilson often so fondly appears unrecognizable. In the play's prologue Stool Pigeon says, “Times ain't nothing like they used to be. Everything done got broke up. Pieces flying everywhere. Look like it's gonna be broke up some more before it get whole again" (Wilson, King Hedley II 7). The Hill District's "spiritual and practical truthsayer" (5) attempts to heal the fractures he sees by hoarding so many newspapers his neighbor Ruby labels his house a "firetrap" (27). He tells Ruby's son King and his friend Mister that he keeps them so "I know what went on. I ain't saying what goes on ... what went on. You got to know that. How you gonna get on the other side of the valley if 
B E L L : S U B VERT IN G THE R O LE O F LE S L I E UX D E M E M O I R E : A L A G A S YRUP AS A SYMBOL IN KING HEDLEY II
August Wilson Journal
Vol. 2
Sum mer 2020

you don't know that? You can't guess on that ... you got to know" (Wilson 27). Stool Pigeon's declaration echoes Nora's theory of the importance of preserving history for minorities because doing so allows these communities to own a sense of their own history, rather than have it articulated by the majority. But what of Alaga Syrup? What of this curious billboardthis "artifact" of history-Wilson so deliberately inserts on the stage?

Briefly, a further understanding of les lieux de mémoire and their role in Wilson's plays is informative. Although sites of memory are commonly discussed in multicultural texts, surprisingly little in-depth commentary exists in Wilson scholarship. The most important interpretations are found in Elam's seminal study The Past as Present in the Drama of August Wilson. For Elam, most sites of memory in Wilson's drama offer warm remembrances and moments of redemption for the characters, which, again, is Nora's claim about their function. For example, the scholar notes that when characters in Seven Guitars perform the Jump Back dance to celebrate Joe Louis's successful heavyweight title defense against Billy Conn, the moment "recalls with nostalgia a time in the forties when swing dancing and the Jump Back were the vogue" (22). Furthermore, when the male characters in The Piano Lesson sing the blues song "Ol Berta," they reenact a performance whose meaning acts as a memory "practically enabling survival [on the] notorious Parchman work farm," the prison where the men learned the song (29). A similar moment occurs in Fences when Cory and Raynell sing a blues song originally passed down by their grandfather. Elam notes "within this interlude of song the past makes an indelible impact on the present, as memory and history congeal in this [site of memory] on the Maxson steps. The song is material, symbolic, and functional, as shared benediction for Troy but also a catalyst for reconsideration, reconciliation, and renewal" (53). Finally, Elam argues that Aunt Ester, Wilson's nearly four-hundred-year-old embodiment of African American tradition, "[b]orn with the arrival of Africans in America . . . is the actual site of African American legacy, a living lieu de mémoire. . . History and memory congeal in her body ... [The name] 'Aunt Ester' is in fact the 'ancestor,' the connection to the African American past, that is both personal and collective, both material and metaphysical" (185). With the exception of Seven Guitars, a play with a rather ambivalent ending, all of these les lieux de mémoire Elam notes complement the general tone of optimism found at the end of the plays mentioned.

This optimism is not present in King Hedley II. Aunt Ester dies in this play, in part because the Black community turns its back on her. Even before her death, Stool Pigeon says, "the path to her house is all grown over with weeds, you can't hardly find the door no more" (8). The entirety of his opening monologue leaves little room for the kind of warmth and nostalgia that appears in the form of les lieux de mémoire in some of the American Century Cycle plays that precede King Hedley II. At first glance, incidentally, the Alaga Syrup billboard appears to meet this pattern of memory as a balm for afflicted communities, especially for those individuals who remember the product and the cultural icon, Willie Mays, who endorsed it. However, a careful examination of the company's advertising practices throughout the twentieth century reveals how it invoked the past as a way of combating a perpetually turbulent present, regardless of the actual time period or target audience. This creates a false sense of nostalgia in regard to Alaga Syrup. Therefore, instead of portraying Alaga Syrup as the kind of lieu de mémoire that invokes warmth and nostalgia, Wilson subverts this traditional role of a site of memory, as the Alaga billboard complements the sense of tragedy that defines the play, and, ultimately, stands as a symbol of the slow decline of the Hill District that Wilson depicts in the plays of the American Century Cycle that take place during the second half of the twentieth century. 


\section{A Brief History of Alaga Syrup’s Advertising}

Founded in 1906, the Alabama-Georgia-Syrup Company's signature product became Alaga Syrup. The company was white owned. The name "Alaga" is a portmanteau Alabama and Georgia (Alaga Syrup). Throughout the twentieth century, the Alabama-Georgia-Syrup Company worked meticulously to brand itself as the kind of product that evokes warmth, family, and community, as well as being a harbinger of a past that was a better, simpler time for everyone that can be revisited simply by buying and consuming the product. This nostalgia-themed advertising was central to the company from the beginning, even before it began marketing consciously to Black communities throughout the United States. For instance, two years after the company's founding, an advertisement in the Pensacola Journal from December 15, 1908, notes the syrup achieves its flavor using "the old fashioned kettle process," and features a drawing of an antebellum era mammy serving pancakes and syrup to a white family (see Fig. 1).

\section{FIGURE 1}

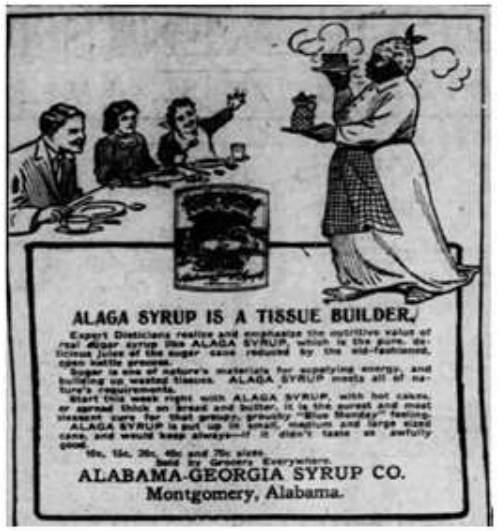

Fig. 1: "Alaga Syrup is a Tissue Builder."

A second ad in the Pensacola Journal on December 19, 1908, features another antebellum mammy tending a kettle of syrup with the copy "The Old Way is the Best Way," claiming all the syrup is manufactured in such a pot and stirred by hand (see Fig. 2).

\section{FIGURE 2}

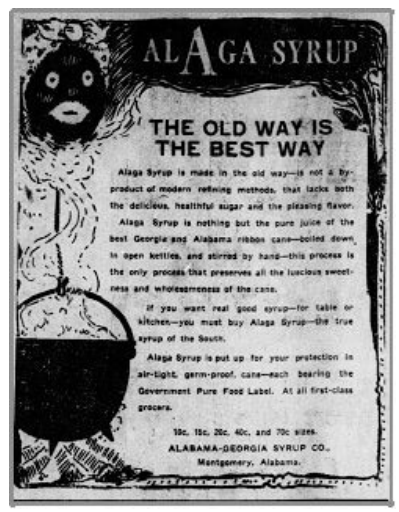

Fig. 2: "The Old Way is the Best Way."

Finally, a third advertisement, also found in the Pensacola Journal from April 3, 1909, eliminates the mammy but asserts that the syrup is "made honestly by the old 'befoh de wah' process" (see Fig. 3). 
FIGURE 3

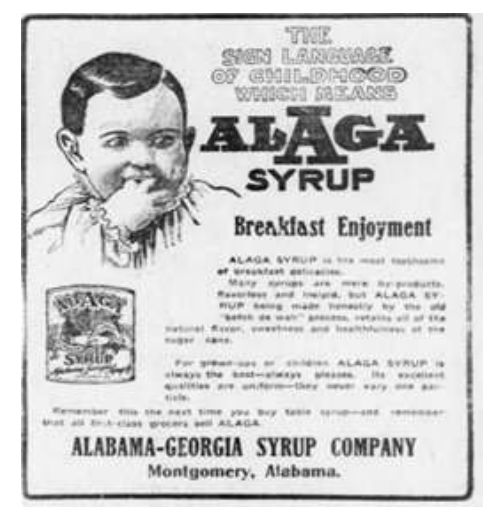

Fig. 3: "The Sign Language of Childhood which Means Alaga Syrup Breakfast Enjoyment."

Collectively, these advertisements show that, from its inception, the Alabama-GeorgiaSyrup Company appealed to its consumers sense of nostalgia, seeking to have its products be associated with its consumers' memories, however intangible. Of course, such intangibility is irrelevant. The syrup itself provides the memory.

What, if any, effect these early advertisements had on Black communities in the South cannot be determined. But in continuing to trace the history of Alaga advertising, one sees that the company had gravitated toward the Black community with a certain vigor by the 1920s. In order to ascertain Alaga Syrup's presence in the Hill District, one may start with the archives of The Pittsburgh Courier, the city's Black newspaper. A search for "Alaga Syrup" within these archives results in 119 hits. By contrast, the same search in the Pittsburgh PostGazette, the most widely distributed newspaper throughout the city, proffers no results. This suggests that Alaga Syrup exclusively targeted a Black clientele in Pittsburgh. Specifically, the archives reveal that Alaga Syrup advertised in the Courier intermittently between 1924 and 1933, including print commercials, promotions for the "Alaga Cane Syrup Radio Hour" broadcast from the fifty thousand-kilowatt radio station WLW in Cincinnati, and coupons. As with the advertisements in the Pensacola Journal noted above, the copy in the Pittsburgh Courier illustrates the company attempted to capitalize on the nostalgia for their homes transplanted Southern Blacks most certainly felt when they arrived in Pittsburgh in droves during the Great Migration North of the early twentieth century. The earliest ad found in The Pittsburgh Courier archives, printed in 1924, features the copy "It's the South's finest syrup sweet and delicious" (see Fig. 4).

\section{FIGURE 4}

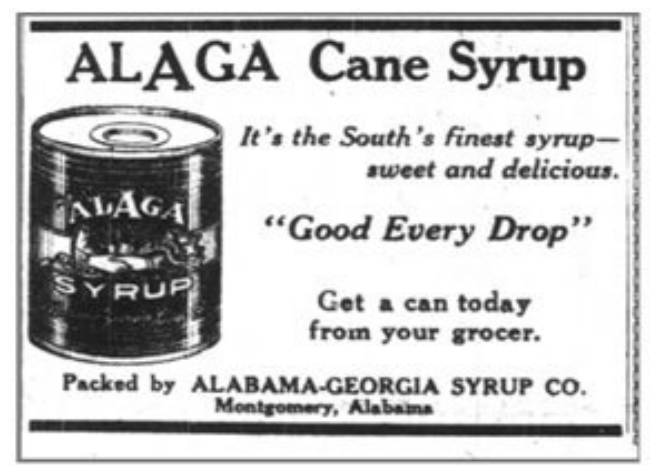

Fig. 4: "It's the South's finest syrup - sweet and delicious. The Pittsburgh Courier. 
Another advertisement published four years later proclaimed it "a Southern favorite for years" and encouraged its target audience to "Buy a can today . . . and enjoy an old-time breakfast of hot cakes and Alaga syrup" (see Fig. 5).

\section{FIGURE 5}

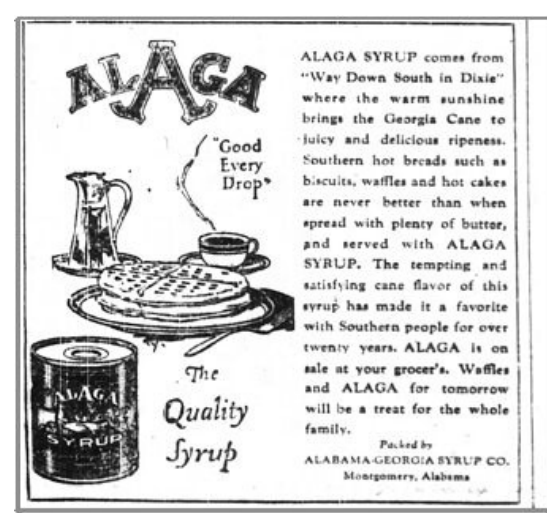

Fig. 5: "Good Every Drop." The Pittsburgh Courier

Yet another advertisement that appeared in the Courier in 1930 reads "Alaga Syrup comes from 'Way Down South in Dixie' where the warm sunshine brings the Georgia Cane to juicy and delicious ripeness...The tempting and satisfying cane flavor has made it a favorite with Southern people for over twenty years" (see Fig. 6).

\section{FIGURE 6}

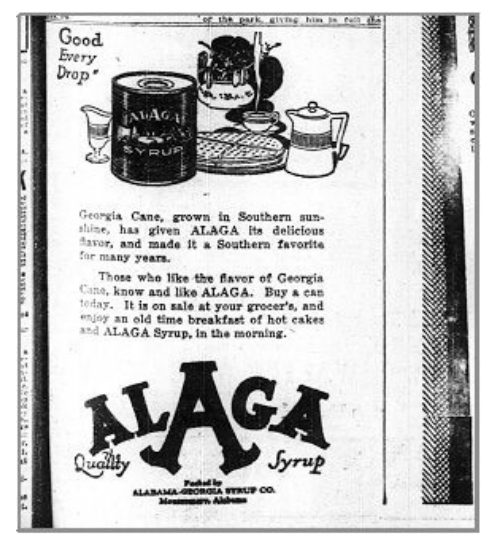

Fig. 6: "Good Every Drop." The Pittsburgh Courier

Finally, in 1931, the most overt appeal to nostalgia appears: "Folks who have lived in the South never forget the delicious taste of Georgia Cane[,]" which has been "a Southern favorite for over twenty years" (see Fig. 7). 


\section{FIGURE 7}

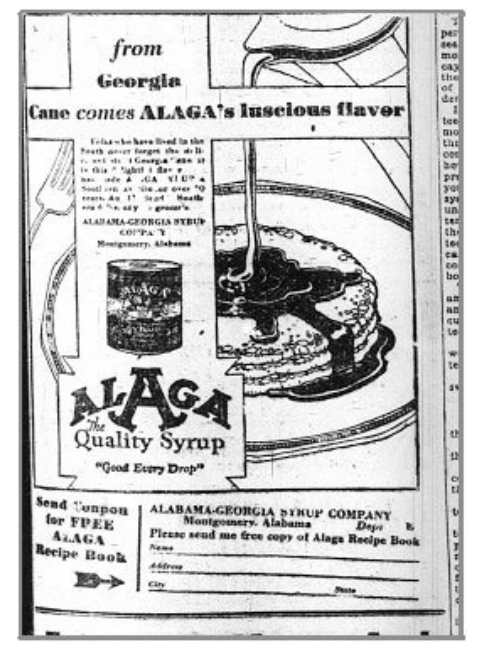

Fig. 7: “from Georgia Cane comes Alaga Syrup.” The Pittsburgh Courier.

Again, although its target audience changed (there were no more mammies in the Pittsburgh Courier ads after all) the Alabama-Georgia-Syrup Company peddled itself as a harbinger of warmth and nostalgia for a nearly thirty year period, solidifying the company as a vessel of sorts to transport its consumers back to a happier past without having to actually leave the kitchen. Although advertisements for Alaga Syrup do not appear in The Pittsburgh Courier archives after the 1930s, the company continued marketing to the Black community. Deborah Jean Warner notes, "Following World War II . . . the Alabama- Georgia Company acknowledged that 'Negroes' were their best customers" (129). Advertisements for the syrup ran in Black newspapers such as the Chicago Defender and the New York based Amsterdam News. In the 1950 os and 1960s, superstar baseball players Hank Aaron and Willie Mays appeared in many advertisements for Alaga Syrup, including ones for Ebony magazine, starting in 1955. These ads ran monthly for many years (248). The Willie Mays advertisement Wilson probably had in mind for King Hedley II appeared around this time (see Fig. 8).

FIGURE 8

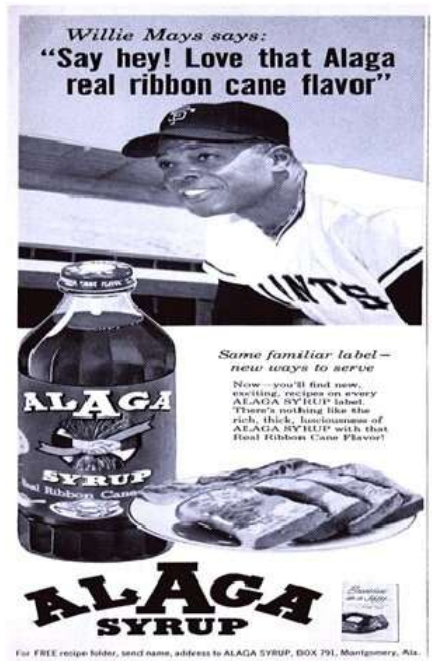

Fig. 8: "Willie Mays Says: 'Say hey! Love that Alaga real ribbon Cane flavor." 
All of these ads show that the Alabama-Georgia-Syrup Company continued its practice of appealing to nostalgia during these years. For instance, both the Hank Aaron and Willie Mays ads featured the copy, "Hank Aaron says, 'I was raised on Alaga Syrup," and Willie Mays says, 'I was raised on Alaga Syrup."

\section{Impact on the Black Community}

Another key to understanding Alaga Syrup as a lieu de mémoire is to recognize the impact it had on the Black community. The Syrup is mentioned in African American fiction, nonfiction, and in general history studies. For instance, Edna Stewart's legendary soul food diner on Chicago's West Side "was a gathering place for civil rights activists who spent fifteen cents for a plate of corn bread drenched with the syrup" (Warner 129). In 1971, the Chicago Tribune featured an article about a Black family living in the traditionally white Oak Park neighborhood who found its neighbors accommodating but lamented that Alaga could not be found on the shelves of that community's grocery stores (129). Furthermore, in Toni Morrison's The Bluest Eye, narrator Claudia McTeer notes that her mother's loving ministrations when she is sick as a child are "Thick and dark as Alaga syrup" (12). The poet Carmen Gillespie writes fondly of Alaga, noting "I can remember my grandmother always had a bottle of it in her pantry ... its dark color and its viscosity never failed to hold my attention" (10). Also, in a special tribute to jazz singer Diane Reeves published in the St. Louis Dispatch, Yanick Lamb Rice celebrates how the vocalist "Through song, constantly reminds [African Americans] to cherish our history and to draw strength from the roots of our family trees," noting that "her concerts feel like church when she riffs about those hugs and kisses, Alaga syrup and biscuits, paper bag curlers, and Vaseline-shined shoes" (471). These sources illustrate how ingrained the company became within the African American community, particularly those who came of age in the immediate Post-World War II era. They also show how successful the Alabama-Georgia-Syrup Company marketing practices were. The nostalgia the brand made central to its advertisements seamlessly ingrained itself in the memories its consumers had of the product long after its availability in most Black communities disappeared.

\section{Alaga Syrup Today}

By the mid-1970s Alaga Syrup was no longer the primary source of profit for the Alabama-Georgia-Syrup Company, nor was it still marketed specifically to Black communities. At some point, the company was folded into the larger Whitfield Foods company, which made its foray into the co-packing business, eventually securing contracts with Ocean Spray, Minute Maid, Nestle, Campbell's Soup, and Pepsico. Today, Alaga is still available, but "both the original syrup and other varieties account for just a fraction of the business" (Azok). However, the company still markets the syrup nostalgically. The current website for Alaga Syrup revels in the company's beginnings, featuring the following copy: "1oo years ago, ALAGA Syrup Company found the secret formula for the 'Sweetness of the South' when the original cane syrup recipe was created in 1906. ALAGA syrup was born out of love, and the 'feeling of family' when a Georgia boy met and married an Alabama girl" ("Alaga Syrup"). The website proudly displays its history of celebrity spokespersons such as Clark Gable, General Jimmy Doolittle, Nat King Cole, Scott and Zelda Fitzgerald, Ernest Hemingway, Hank and Audrey Williams, Hank Aaron, Paul "Bear" Bryant, and Shug Jordan. Willie Mays appears to be the celebrity the company is most proud of being associated with, as two ads featuring him are the only ones reproduced on the website. The pre-World War I ads from the Pensacola Journal featuring mammies are not mentioned. 
B E L L : S U B VERT IN G THE ROLE O F LES L I E UX D E M E M O I R E : A L A G A S YRUP AS A SYMBOL IN KING HEDLEY II

\begin{tabular}{l|l|l|l} 
August Wilson Journal & Vol.2 & Summer 2020
\end{tabular}

\section{A Reading of King Hedley II}

Armed with this history, we can examine the Alaga billboard within the context of King Hedley II. As noted, audience members who recognize the company, the billboard, or both, probably have fond remembrances of the syrup. And, as Elam notes, such is the function of sites of memory in Wilson's plays. One is tempted to see the Alaga billboard in a similar fashion. After all, Alaga is a food product, and, as Psyche Williams-Forson points out, "Food not only celebrates belonging, but in Black communities it represents resourcefulness and ingenuity, even as it nourishes, fulfills, and sustains" (129). But the Alaga billboard is hollow. The product was unavailable in the Hill by 1985 , a time in which the neighborhood was considered a "food desert," a condition in which the residents of an area do not have access to affordable, healthy food choices. The age of the billboard, no less than twenty years old, enhances the sense of abandonment and lack of opportunity in the Hill in 1985, which Wilson prominently depicts in the play. King, the titular character, finds only one legitimate means of employment, working for a local contractor named Hop, who tears down blighted buildings when the city approves his contracts. Unfortunately for King, Hop has to fight the city to honor these contracts. In the meantime, he and his friend Mister sell refrigerators stolen by an unnamed third party, squirreling away money in hopes of opening a video store specializing in kung fu movies. Later, the two rob a jewelry store, hoping to inject more capital into their business plan.

Interestingly, the conditions King faces are the result of years of institutionalized racism, which Wilson depicts in the plays that comprise the second half of the American Century Cycle. The Alaga billboard can be imagined as a central symbol of this time period. As noted earlier, in the 1950 os the city of Pittsburgh enacted a plan that led to the destruction of the Lower Hill district, which displaced thousands of residents and shuttered hundreds of businesses. The city never followed through on its promise to rebuild the area it declared blighted, the effects of which become central to Wilson's chronicle of the Hill, beginning with Fences, set in 1957, and continuing through to the end of the cycle. In fact, one can imagine the Alaga Syrup billboard already in place by the late 1950s. After all, Willie Mays was endorsing the product by this time. A direct connection can be made between Fences and King Hedley II. In the former, Troy argues with his wife, Rose, about shopping at Bella's instead of the A\&P. Bella's was an independent grocery store, formally Siger's Grocery (named after its owner, Bella Siger), that operated at 1727 Bedford Avenue for decades. This is the actual location of the setting for King Hedley II. In Seven Guitars, a companion play of King Hedley II set in 1948, Louise reminds Hedley (King's namesake) his rent is due, declaring, "You pay me tomorrow, you know how Bella is about her money" (Wilson, Seven Guitars 22). Later Louise trips over the back stairs and says "Bella need to fix these steps. She been saying that for the longest time" (93). Bella Siger rented apartments out of the back of grocery store, one, in fact, to Wilson's family for nearly two decades. Fast forward to King Hedley II in 1985 and readers learn that King was raised by "Mama Louise," who dies off stage shortly before the play begins. Elam offers a bleak connection between the two plays: "The lively backyard of some forty years earlier in Seven Guitars is now in a state of fragmented ruin" (69). Therefore, King, born in 1949, has lived in the shadow of the Alaga Billboard nearly all his life, watching his neighborhood decay while the advertisement stubbornly remains in place.

The connections between the different Wilson dramas are deeper than geographical curiosities. One can trace the decay of the Hill with the Alaga Billboard at the center of the discussion, if one imagines the advertisement existing within the context of the plays that take place between 1957 and 1985. As noted, in Fences Troy and Rose argue about shopping at Bella's. For Rose, the value of shopping at the A\&P is purely economic: groceries there are cheaper. For Troy, the sense of community he feels at Bella's is more important. He says to Rose, "The A\&P ain't never done nothing for me. I spends my money where I'm treated right. I go down to Bella, say, 'I need a loaf of bread, I'll pay you Friday.' She give it to me. What sense 
that make when I got money to go and spend it somewhere else and ignore the person who done right by me? That ain't in the Bible" (Wilson, Fences 14). Here readers gauge one of Troy's more admirable qualities: His devotion to his community, illustrated by his spending habits. One might even argue that Troy mirrors a certain familial spirit Alaga promotes in its advertisements, which he could have noticed when shopping at Bella's. In Two Trains Running, however, set a little more than a decade later, this spirit appears ineffective because the effects of urban renewal have crippled the Hill District. This play is set in Memphis Lee's diner. Memphis announces that the city plans to forcibly purchase his building and intends to demolish it. He laments the state of the Hill in 1969: "Ain't nothing gonna be left around here. Supermarket gone. Two drugstores. The five and ten. Doctor done moved out. Dentist done moved out. Shoe store gone. Ain't nothing gonna be left but these niggers killing one another. That don't never go out of style" (Wilson, Two Trains Running 14). Of course, the Alaga Billboard, most certainly in place by this time, persists even if the product will soon be off the shelves in the Hill. This perspective is only worsened in the next play in the American Century Cycle, Jitney, set in 1977. Part of the plot is concerned with a group of drivers who operate a marginally illegal taxi service. Jitney drivers are vital for Hill District residence, as licensed cab companies will not serve the neighborhood. Like Memphis in Two Trains Running, Becker is told that the city plans to demolish the building, threatening the livelihood of the drivers. In the second act of the play, the drivers discuss the pending demolition, and Wilson offers his most scathing commentary on the effects of urban renewal on the Hill in the following exchange between the drivers:

BECKER: All right ... You all know why we're here. You all know what's happening. The city's fixing to board up the place come the first of the month. They gonna tear it down. They gonna tear the whole block down.

YOUNGBLOOD: They gonna tear the whole neighborhood down.

DOUB: They supposed to build some houses. That's what they need to do.

TURNBO: They supposed to build a new hospital down there on Logan Street. They been talking about that for the longest while. They supposed to build another part to the Irene Kaufmann Settlement House to replace the part they tore down. They supposed to build some houses down on Dinwiddie.

BECKER: Turnbo's right. They supposed to build some houses but you ain't gonna see that. You ain't gonna see nothing but the tear-down. That's all I ever seen.

YOUNGBLOOD: That's all there is to see. (Wilson, Jitney 67)

The irony is apparent. As the neighborhood persistently declined, the Alaga billboard remained, while the attendant promises invoked in the company's advertising offer no relief in the face of these realities. Rather than warmth and remembrance, this lieu de mémoire serves as a reminder of false and broken promises that defined the Hill District in the second half of the twentieth.

Returning to King Hedley II, the billboard can be seen as something of an anathema. As noted earlier in this essay, King Hedley II is Wilson's bleakest drama. Even the two plays that precede it, Two Trains Running and Jitney, end in harmony, despite their depictions of a steadily declining neighborhood. King Hedley II begins on a dark note and ends in despair. Decades of institutionalized racism that led to the aforementioned lack of job opportunities collide with a myriad of social ills. In the first act, Hedley mentions a child, Little Buddy Will, was killed in a drive-by shooting and that another Black family's house was burned when they attempted to move to the white neighborhood of Shadyside. Tonya, King's wife, offers a devastating contemporary critique of young Black families in the Hill, telling King she is pregnant but plans to have an abortion because she doesn't want her newborn to be older than the child her seventeen-year-old daughter Natasha carries. Anguished about being a grandmother at thirty-five and also, Tonya laments the lack of father figures in most children's 
B E L L : S U B V ERT T N T H E R O L E O F L E S L I E UX D E M E M O R E : A L A G A Y R U P A S A S Y M B L I N K I N G H E D L E Y I I
August Wilson Journal | Vol.2 | Summer2o2o

lives, asserting that Natasha's "daddy in jail. Her step-daddy going to jail. She seventeen and got a baby, she don't even know who the father is" (Wilson, King Hedley II 37). In Act Two Stool Pigeon enters after having been attacked and robbed by a gang of Black youths who steal a mere sixty-three dollars and burn his newspapers. The most devastating event in the play occurs when Aunt Ester dies, signaling that the foundation of the community itself appears to have collapsed. At the end of the play, Ruby accidentally shoots her son. And while the infanticide symbolizes a sacrifice that promises Aunt Ester's resurrection, the immediate horror outweighs the hope. All the while, the Alaga Billboard looms over the stage, an increasingly troublesome sign. The company that worked so consciously to brand itself as the kind of product that offers families "warmth and tradition," to use Pierre Nora's claim of what sites of memory can be, is a negative symbol of a company whose presence on the Hill is perhaps better left to the amber of history (7). Again, because Alaga Syrup cannot be located within the contemporary setting of King Hedley II, the billboard's presence is ironic. What we have is a white owned company which earned a fair amount of profit from the Black community for approximately half a century that eventually took its business elsewhere but did not even take its billboard down before it left town.

\section{Conclusion}

Some audience members who recognize the Alaga Syrup billboard when attending a production or those reading the script of King Hedley II are likely to recognize Alaga Syrup as a lieu de mémoire in the traditional sense, a symbol that evokes a kind of happy reminiscence for those who can identify it. This is certainly the function of sites of memory in some of August Wilson's plays, such as when characters perform the Jump Back dance in Seven Guitars, or when Troy, his son Cory, and his daughter Raynell sing a blues song passed down from generation to generation. However, the Alaga billboard fails to evoke such sentiment. Examining the history of Alaga Syrup's advertising confirms that the company manipulated a sense of nostalgia throughout its history, regardless of its audience. After all, the syrup was marketed to white communities before the company almost exclusively targeted Black ones. Wilson ultimately shows a certain indifference the company had in regard to its marketing practices, as it left the billboard in place, even after the product itself could no longer be found within the Hill District by 1985, the year King Hedley II is set. This indifference complements the attitude of the most powerful individuals who run the city of Pittsburgh itself, the very people who enacted the urban renewal plan that led to the systematic destruction of the Hill District in the second half of the twentieth century, wherein hundreds of businesses were destroyed and thousands of citizens were displaced, while virtually nothing was built to replace that which was demolished. One can imagine the Alaga Billboard stubbornly looming over Bedford Avenue for nearly the entirety of the second half of the twentieth century, as so much decays around it. One is left with the impression that syrup will not mend the ills of the community, however nostalgic the feeling. Such is how August Wilson subverts the role of a lieu de mémoire in King Hedley II.

\section{Works Cited}

"Alaga Syrup. About Whitfield Foods and Alaga Brand Products." https://www.alagasyrup.com/about_us. Accessed 22 Feb 2020.

"Alaga Syrup is a Tissue Builder." Pensacola Journal, 15 Dec. 1908, p.5. Newspapers.com, https://www.newspapers.com/image/80943832.

Bigsby, Christopher. "An Interview with August Wilson." The Cambridge Companion to August Wilson. Edited by Christopher Bigsby, Cambridge UP, 2007, pp. $202-213$. 
Gillespie, Carmen. "Wintergreen and Alaga Syrup: A Writer's Reflections on Memory, Writing, and Place." Shaping Memories: Reflections of African American Women Writers, Edited by Joanne Veal Gabbin, U of Mississippi P, 2009, pp. 7-13.

"Good Every Drop." The Pittsburgh Courier 14 Apr. 1928, p. 9. Newspapers.com. https://www.newspapers.com/image/40008512.

---. The Pittsburgh Courier 23 Aug. 1930, p. 7. Newspapers.com. https://www.newspapers.com/image/40068568.

Elam, Harry. The Past as Present in the Drama of August Wilson. U of Michigan P, 2004.

"from Georgia Cane comes Alaga Syrup." The Pittsburgh Courier 21 March 1931, p. 7. Newspapers.com. https://www.newspapers.com/image/40035520.

Herrington, Joan. "King Hedley II: In the Midst of all this Death." The Cambridge Companion to August Wilson, Edited by Christopher Bigsby, Cambridge UP, 2007, pp. 169-182.

"It's the South's finest syrup - sweet and delicious. The Pittsburgh Courier. 12 April 1924, p. 2. Newpapers.com. https://www.newspapers.com/image/80943832.

Lamb, Yanick Rice. "Happy Anniversary! A Year Old; A Million Strong." St. Louis PostDispatch 2 Feb. 1997, p. 471.

Morrison, Toni. The Bluest Eye. Vintage, 1970.

Nora, Pierre. "Between Memory and History: Les Lieux de Mémoire." Representations, Spring 1989, pp. 7-24.

“The Old Way is the Best Way." Pensacola Journal 19 Dec. 1908, p. 3. Newspapers.com. https://www.newspapers.com/image/80943832.

Shannon, Sandra. "Turn Your Lamp Down Low! Aunt Ester Dies in King Hedley II. August Wilson: Completing the Twentieth Century Cycle, edited by Alan Nadel, University of Iowa P, 2010, pp. $123-133$.

"The Sign Language of Childhood which Means Alaga Syrup Breakfast Enjoyment." Pensacola Journal 3 Apr. 1909, p. 3. Newspapers.com. https://www.newspapers.com/image/80796260.

Williams-Forson, Psyche. "He gonna give me my ham': The Use of Food as a Symbol for Social Justice." August Wilson's Pittsburgh Cycle: Critical Perspectives on the Plays. Edited by Sandra Shannon, McFarland, 2016, 128-141.

"Willie Mays Says: 'Say hey! Love that Alaga real ribbon Cane flavor." http://bp2.blogger.com/ thlFYTjJbmQ/RioG6ewidHI/AAAAAAAAATg/sonrFoxFU EM/s128o-h/williesyr.JPG.

Wilson, August. Fences. Theatre Communications Group, 2007.

---. Jitney. Theatre Communications Group, 2007. 
B E L L: S U B VERT TNG THE R O LE O F LES L IE U X DE M E MO I R E : A L A G A S YRUP AS A SYMBOL IN KING HEDLEY I I

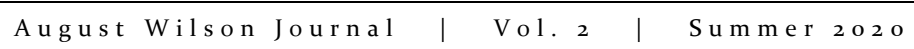

---. King Hedley II. Theatre Communications Group, 2005.

---. Seven Guitars. Theatre Communications Group, 2007.

---. Two Trains Running. Theatre Communications Group, 2007.

\section{Author Bio}

Dr. Christopher Bell is Associate Professor of English at the University of North Georgia where he teaches courses in American Literature, African American Literature, and World Drama. 